Kampus 4 Universitas Ahmad Dahlan Jl. Ringroad Selatan, Tamanan, Banguntapan, Bantul

Daerah Istimewa Yogyakarta 55191

Telp. : (0274) 563515 Fax. : (0274) 564604

e-mail : ihtifaz@uad.ac.id

Vol.1, No 1\&2, Juni-Desember 2018, pp. 33-50

ISSN p:2622-4755 e:2622-4798.

DOI: https://doi.org/10.12928/ijiefb.v1i1.284

The Role of Religiosity, Halal Awareness, Halal Certification, and Food Ingredients on Purchase Intention of Halal Food

\author{
Lu'liyatul Mutmainah ${ }^{1 *}$ \\ ${ }^{1}$ University of Indonesia, Kukusan, Depok, Kota Depok, Indonesia \\ *e-mail: sakinah.lym@gmail.com
}




\section{The Role of Religiosity, Halal Awareness, Halal Certification, and Food Ingredients on Purchase Intention of Halal Food}

\author{
Lu'liyatul Mutmainah ${ }^{{ }^{*}}$ \\ ${ }^{1}$ University of Indonesia, Kukusan, Depok, Kota Depok, Indonesia \\ *e-mail: sakinah.lym@gmail.com
}

\begin{abstract}
Halal becomes the lifestyle of Muslim consumers in the world. As the Muslim population increasing, the awareness on consuming halal food also improving. This paper aims to examine the influence of religiosity, halal awareness, halal certification, and food ingredients on purchase intention of halal food among Indonesian Muslim consumers. Convenience sampling was used as the sampling method of this study. This research consisted of 205 respondents. The data are collected by questionnaire which are analyzed by multiple linear regression. The results of this study revealed that religiosity, halal awareness, halal certification and food ingredients have significantly positive effect on purchase intention of halal Food. This study indicates that consuming halal food is primary need for Muslim. Therefore, company should acquire halal certification in order to provide halal food for Muslim's needs. This study contributed for the research literature, government, food manufacturers and marketers to develop strategies related with halal food.
\end{abstract}

\section{Keywords:}

Religiosity, Halal Awareness, Halal Certification, Food Ingredients, Purchase Intention.

\begin{abstract}
Abstrak
Halal menjadi gaya hidup konsumen Muslim di dunia. Seiring meningkatnya populasi Muslim, kesadaran untuk mengonsumsi makanan halal juga meningkat. Tulisan ini bertujuan untuk menguji pengaruh religiusitas, kesadaran halal, sertifikasi halal, dan bahan makanan pada niat pembelian makanan halal di kalangan konsumen Muslim Indonesia. Convenience sampling digunakan sebagai metode sampling penelitian ini. Penelitian ini terdiri dari 205 responden. Data dikumpulkan dengan kuesioner yang dianalisis dengan
\end{abstract}

Ihtifaz: Journal of Islamic Economics, Finance, and Banking

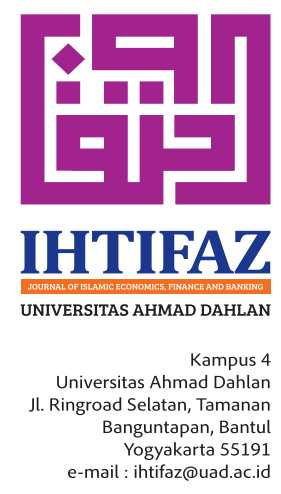

Vol.1, No 1\&2, p. 33-50, ISSN p:2622-4755 e:2622-4798 
regresi linier berganda. Hasil penelitian ini mengungkapkan bahwa religiusitas, kesadaran halal, sertifikasi halal dan bahan makanan memiliki pengaruh positif IHTIFAZ - JIEFB yang signifikan terhadap niat pembelian Makanan halal. Studi ini menunjukkan bahwa mengkonsumsi makanan halal adalah kebutuhan primer bagi Muslim. Oleh karena itu, perusahaan harus memperoleh sertifikasi halal untuk menyediakan makanan halal bagi kebutuhan Muslim. Studi ini berkontribusi untuk literatur penelitian, pemerintah, produsen makanan dan pemasar untuk mengembangkan strategi yang berkaitan dengan makanan halal.

\section{Kata Kunci:}

Religiusitas, Kesadaran Halal, Sertifikasi Halal, Bahan Makanan, Niat Beli

\section{INTRODUCTION}

Islam is a religion that guides human behavior in all aspects of life. One of guidance in Islam regulates the behavior of human consumption. In the Qur'an has also been mentioned about what is lawful and unlawful for human consumption (Al Maidah: 3; Al Baqarah: 173). In addition, the Qur'an also explains that a Muslim is recommended to consume halal and good food (Al Baqarah: 168; Al Mu'minun: 51). Therefore, the halalness of food and drink is a major consideration for a Muslim.

The religious belief lead a Muslim to do what is commanded and forsaken, also what is forbidden by God. Machali et al. (2013) says that in Islam, the concept of halal is the main key in consumption. Bonne and Verbeke (2006) also explains that Muslim consumers consume halal meat with the aim of following and express their religious teachings. Jamal (2003) also argues that commitment religion and faith affect the feelings and behaviors of people in consumption (Machali et al., 2013: 1).

Consumer's consideration related to halal food is not just to meet the need for religious doctrine, but also to ensure security of the food. According to Market Brief ITPC Osaka (2013) in Alfarisi (2017: 2) states that halal food is not only concerned with religious issues, but also in context business and trade related to lifestyle and quality assurance. This is evidence that the halal market continues to grow supported by increased awareness of its importance quality and safety of the product. In addition, this indicates a shift in perception consumers to the concept of halal. According to the Economic Council (2011), the halal market is growing fast and an increase of about $25 \%$ per year (Waskito, 2017: 2). The halal market is also predicted to achieve US $\$ 80$ billion a year globally and the halal food industries estimated growth rate is $7 \%$ annually (Aziz \& Viu, 2013: 2).

The development of halal industry is not only found in Muslim countries. Enhancement of Muslim populations in non-Muslim countries contributes to the high number of halal industry needs, especially halal food products for Muslims themselves. Increasing Muslim population in 
this world also encourage increased awareness of Muslim consumers to halal a product. The population of Muslims in the world is predicted to continue to increase to reach $30 \%$ the population of the earth by 2050, this number is equal to the population of Christians in the world (amp. dw.com). According to research from Pew Research Center, predicate of Indonesia as a country with the largest Muslim population currently also predicted to be taken by India in 2050. Islam will be the largest religion in the world by 2075 . It is now largely Muslims live in the Asia

Journal of Islamic Economics, Finance, and Banking

Vol.1, No 1\&2, Juni-Desember 2018, Pp. 33-50, ISSN p:2622-4755 e:2622-4798 and Pacific region, such as Indonesia, India, Pakistan, Bangladesh, Iran and Turkey (www.bbc.com). Muslims projected to be fastest-growing major religious group. There will be $31.1 \%$ of Muslims world population projected in 2060 (Pew Research Center, 2017). Therefore, the provision of consumption needs of Muslims as well will continue to increase.

Fulfilling the needs of Muslim consumption is different because of the demand for eating halal and good food, even though the Muslims live in a non-state Muslim. Therefore, it is necessary to increase awareness of the consumption of halal food. According to Riaz and Chaundry (2004), several factors that influence consumption are religion, race, knowledge, perception and others. Islam forbids khamr, pigs, dogs and others. Jewish also has a rule called Kosher, while Hinduism and Buddhist set not to eating cattle or being vegetarian (Alfarisi, 2017).

Shaari and Arifin (2010) explain that the awareness of halal is the level of knowledge Muslim consumers to find and consume halal products in accordance with the Sharia. The development of research related to halal awareness of several years is increasing rapidly (Ardyanti et al. 2013; Windikusuma, 2015; Waskito, 2017). Halal food is also a power pull business in non-Muslim countries (Ardyanti et al., 2013). According to The Halal Journal (2008), the estimated total industry of goods and services using halal appeal is worth more than \$ 1 USD trillions in the world, including tourism and hospitality sectors (restaurants and hotels with sharia compliance) finance, beauty, and so forth (Waskito, 2015: 2-3).

Yunus et al., (2013) states that the halal consciousness of a Muslim has an influence significant to consumer purchase intention (Waskito, 2017). If the consumer has halal awareness, then the purchase intention becomes high and consistent to the halal product only. Therefore, the company will feel required to acquire or maintain halal certification. This has become one of the marketing strategies also for the company to obtain consumer.

Halal awareness is not only seen from the point of view of consumers, but also from the point of view of the manufacturer. There are many Muslim consumer in Indonesia still buy food in restaurant without halal label. It also affects the manufacturer or food entrepreneurs not to register their products in order to obtain halal certification (Waskito, 2017). 
The need of halal food for Muslim countries like Indonesia would be very important and should be well managed and correct. The presence of halal labels on food products is a special consideration for Muslims. However, these halal labels do not just represent that the product is lawful for Muslims. In addition to guarantee the halalness of a product, label It should also be a guarantee of security, quality, and cleanliness a product. This is also to ensure that this product is not only for Muslims because of its halalness, but also for anyone will feel safe to consume the product. So consumers will have an interest in buying these halal food products.

Halal labelling on the product becomes a sign that the product has been certified halal which is tightly tested. Halal certification is a guarantee of security for people Muslims to be able to consume a product (Aziz and Vui, 2013). A research on Singapore in 2006 showed that McDonald's in the country is experiencing an increase in the number of visits by 8 million visits after obtaining halal certification. While sales of KFC, Burger King and Taco Bell also increased by $20 \%$ after obtaining halal certification (Lada, et al., 2009). This indicates an influence halal certification of consumer purchase intention. Consumers who may be hesitant to consume the product to be assured once there is a certifying institution halal to the producers.

This halal certification involves not only the products to be consumed directly by consumers. However, it involves all aspects of the production chain such as equipment used and other materials added to the product. Existing food products on the market today many come from abroad. There are many foreign foodstuffs may not exist in Indonesia. In addition, the use of foreign terms in the composition of the material food is widely available in instant food products that much-loved the community. With current media and technology roles, consumers should have a higher awareness to know the composition of food on a product. Food ingredients become one of the decisive factors in predicting how purchase intention consumers to food product (Johri and Sahasakmontri, 1998 in Waskito, 2017: 5). Hussain et al. (2013) say that the composition of the material contained in the product has a negative influence on consumer purchase intention (Waskito, 2017).

Based on the description above, there is a research gap related to factors that affect consumer purchase intention on halal products. This research is focused on knowing the halal awareness of Muslims and see the role of religiosity, halal awareness, halal certification, and food ingredients on effecting purchase intention of halal food.

\section{LITERATURE REVIEW}

\section{Halal Concept}

Islam has laws and sharia that regulate the daily life of Muslims. This Islamic law and sharia covers all aspects of the most basic things, 
including within consumption behavior. Yusoff (2004) explains that Islam has three related legal categories this is halal, haram, and subhat. Halal means permissible and lawful, haram means not allowed and illegitimate, while subhat means dubious, still in question and should be avoided (Waskito, 2017). Suggestions related to halal and haram food poured in the verses of the Qur'an (Al Baqarah: 168; Al Maidah: 3; Al Maidah: 88; Al Maidah: 90; Al Mu'minun: 51).

Islam teaches to pay attention to halal, like food and material which is used must also be halal, there should be no mix of prohibited goods in the production process, cooking, and serving. There is a special purpose of this concept of halal in Islam, that is to maintain purity of life and maintaining ethics, attitudes and behavior (Hussain, 2016: 36).

\section{Purchase Intention}

According to Assael (2001), purchase intention is the tendency of consumers to buy something or take action relating to buying and measuring at the likelihood level consumers make purchases (Waskito, 2017: 17). The attitude and behavior of buying from someone must be based on intentions or tendencies with a variety of considerations.

Purchase intention is the stage of a person's tendency to act before a decision buy is actually done. Purchase intention is the same as the intention to make a purchase in the future to come (Windikusuma, 2015: 17). Listyoningrum and Albari (2012) showed that there are differences in attitudes and purchase intention of Muslim consumers who know and not knowing about halal certification extension from any of the bakery products.

Shaari and Arifin (2010) found the existence of 9 dimensions in measuring halal purchase intention. These dimensions are solidity, certainty, universal, brand association, purity, conformity, halal-ness, place \& distribution and knowledge. This dimension is generated from extraction through Varimax Factor Analysis from marketing concept variables, awareness, halal certification and religiosity.

\section{Religiosity}

Religiosity is the appreciation of one's religion including symbols, beliefs, values and behavior driven by spiritual forces (Fatmawati and Pramintasari, 2017: 743). Every religion has its own rules about what is and is not allowed to be done. This is included in consumption behavior, so that religion can be the basis of religious beliefs in his consumption behavior.

Consumption behavior according to Islamic Sharia has been taught and stated in several verses The Qur'an (Al Baqarah: 168; 172-173; Al Mu'minun: 51; Al Maidah: 3). Basically, the rule in Islam which concerns all aspects of human life is for the benefit man himself. People who have 
different religious experiences are likely have different consumption behaviors. Different consumption experiences can also affect his life.

For example people who violate God's command with drink khamr or eat pork, then it will also affect the behavior and his attitude, including his worship. This is because all disobedience will reduce blessing and peace in life.

Study conducted by Hussaini (1993) mentioned that $75 \%$ of migrants Muslims in the United States continue to follow his religious rules of eating (Yasid, et al., 2016: 29). This shows that one's religious beliefs are an important and important source of behavior, including consumption behavior. Result of study from Ahmad et al. (2015) also shows that religiosity is more influential to behavior compared with halal related knowledge. In addition, there are differences significant on the behavior of respondents to halal food products and halal cosmetics products. Accordingly, the following hypothesis is proposed:

$\mathrm{H} 1$ : Religiosity has positive and significant effect on purchase intention.

\section{Halal Awareness}

Awareness is the ability to perceive, to feel, and to be conscious of events and objects. Awareness has been hypothesized as an important role in determining the intention to choose (Aziz \& Viu, 2013: 7). Indonesian consumers already pay attention to halal label. This is evidenced by the increase in sales after the existence of halal label. In 1988 came the issue of lard that caused a decrease in turnover sales of some food products significantly. In addition, issues related to mixing between beef with pork on meat and processed products such as meatballs, formalin chicken and so forth sparked awareness of Indonesian people in choosing halal and good food (Windikusuma, 2015: 14).

According to Allport and Ross (1967), Religious is divided the two kinds of religious ways, they are intrinsic and extrinsic. Instrinsic means incorporating the religious values within, there is religious spiritual internalization and has low prejudice. Extrinsic means there is high in prejudice of the religion, the way of religion extrinsic encourages one to make use of his religion. Review results from Donahue (1985) in Windikusuma (2016) argue that extrinsic religiousness brings humans in the practical dimension religion. These dimensions include worship behavior, obedience, and the things that are done for show commitment to the religion he embraces.

The concept above indicates that people who have an intrinsic halal awareness will implements religious values in all aspects of his life according to belief religion that he embraces. They will really make sure the halal of what is consumed. While people with extrinsic halal awareness will follow the commitment from their religion through the 
information obtained, such as looking at halal information from the products consumed without really finding out more.

Bashir et al. (2018) show that there is a significant influence between awareness and purchase behavior. The interesting thing is only the dimensions of attitudes that have a significant relationship with purchase intention, while subjective norms and behavior control (perceived behavioral control) did not show any significant relationship. Furthermore, study conducted by Machali et al. (2013) shows that level of halal awareness to halal food is high enough, the influence of awareness of purchasing decisions also positive and significant with religiosity as a moderating variable. Based on the explanation, the following hypothesis is:

$\mathrm{H} 2$ : Halal awareness has positive and significant effect on purchase intention.

\section{Halal Certification}

Aziz \& Viu (2013) explain that halal certification is an official recognition of the orderly process of preparation, slaughtering, cleaning, handling, and other relevant management practices by the established body (such as MUI in Indonesia, JAKIM in Malaysia). Halal certification for a Muslim country like Indonesia is paramount importance and a part of obligation. This is because to meet the welfare of Muslims in eating halal food which is assured. Government Regulation No. 69 Year 1999 on Label and Advertisement of Food article 2 paragraph 1 explains that anyone who manufactures or import food packaging to Indonesia to be traded must include the food label. This is actionable continue with the Decree of Minister of Religious Affairs No. 519 of 2001 on Institutions Executor of Halal Food Inspection. In addition, Law No. 8 of 1999 on Consumer Protection also states that the right of consumers including the right to comfort, safety and safety in consuming goods or services. Government too issuing Law No. 33 of 2014 on Halal Product Guarantee due the consideration of existing products in society not all guaranteed halal.

For a Muslim, halal is the main thing, because it makes no guarantees contrary to Islamic principles. Halal consumption behavior can also be a worship because halal goods will bring rewards and blessings. In the Act (Halal Product Guarantee) explained that halal products are products that have been declared halal according to Sharia. While the guarantee of halal products itself is the legal certainty of a halal products proven by halal certification. Halal certification is the recognition of the halalness of a product issued by the Agency The Organizer of Halal Product Guarantee is based on a written fatwa issued by Majlis Ulama Indonesia (MUI). Halal label is a sign of the halal of a product.

Research conducted by Kamilah and Wahyuati (2017) about the influence of halal labeling and brand image of purchasing decisions 
through purchase intention, this research shows that halal labelling positively affects purchasing decisions, however no significant effect IHTIFAZ - JIEFB on purchase intention. While the brand image has a significant effect against purchasing decisions or buying interest. Hence, a hypothesis was conceptualized as follows:

H3: Halal certification has positive and significant effect on purchase intention.

\section{Food Ingredients Composition}

The food consumed contains various components that are mixed before it is ready consumed by humans. Food composition consist of ingredients that are contained within food product. These food ingredients are related to several things need to be considered for Muslim. Consumer knowledge and familiarity with security, halalness, and the quality of the food becomes an important thing that needs to be explored more deeply.

Wandel (2007) said that most consumers are very serious to know what they consume and this food information is generally present on the product label. Conscientious consumers will check the label of the ingredients composition as a knowledge and decision making whether to buy or not (Waskito, 2017: 16-17). In the view of Islam, this becomes something important because the food though a little if not according to Islamic rule, it will affect the halal of the food consumed. Currently, many processed foods from meat or goods that are not justified in Islam, such as pork oil, addition matter of cake made from khamr, even brush for the spread of food also from the pork's fur. Study conducted by Hussain et al. (2016) find that Ingredients positively influence consumer's attitude to buy halal products. Ingredients are the main reasons of concern for both manufacturer and consumers. The ingredients of products motivate consumers to choose or not choose any product. Therefore, the following hypothesis is forwarded:

$\mathrm{H} 4$ : The food ingredients composition has positive and significant effect on purchase intention.

This study aims to see the influence of religiosity, halal awareness, halal certification, and food ingredients of purchase intention of Muslim consumers on halal food products. The research framework presented in this study is as follows:

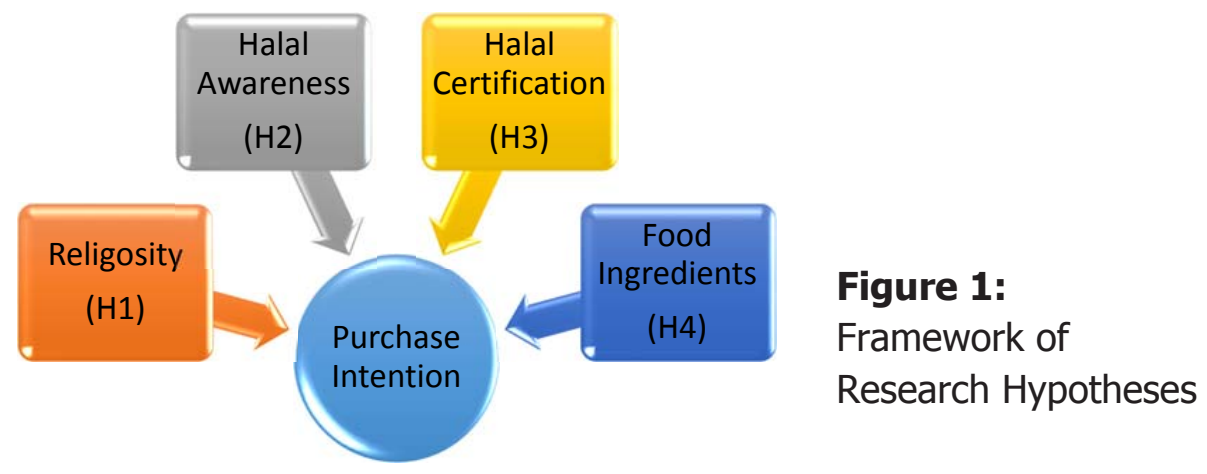




\section{METHODOLOGY}

\section{Sample and Population}

The population used in this study are Muslim consumers in Indonesia who are Muslim and have grown up. Ferdinand (2005) suggested a sample size of 5-10 times the number of indicators coupled with the number of latent variables (Waskito, 2017: 28). In the study there are 39 question indicators, so the minimum sample is 5 multiplied by 39 that is 195 . The sample size of this study consisted of 205 samples. So it meets the minimum amount sample.

The sampling technique used is non probability sampling with convenience sampling. This technique is used because researchers do not know the exact number population and researchers selected a sample based on the population that is easily accessible for get the answer because of the limited time of research.

\section{Data Collection}

The type of data used in this study is primary data and secondary data. Primary data taken through a questionnaire collected from informants in a short time. The questionnaire used is a questionnaire with a likert scale of one to five represent points strongly disagree, disagree, quite agree, agree and strongly agree. Questionnaire designed according to previous research with some modifications to get consumer purchase intention. Secondary data used comes from book, websites and previous literature related to this research.

\section{Data Analysis}

Likert scale used in this research, so it must go through consistency and stability test question on questionnaire with reliability test and validity test (Ghozali, 2011: 42). Test reliability is done by looking at the value of Cronbach Alpha, if the value $>0.60$ then the variable research can be said reliable. While the validity test seen from the calculation of correlation Pearson Correlation . If the correlation value has significant value $<0.05$, then the research question said to be valid. Descriptive statistical analysis is also performed to provide a picture of the data research. Moreover, testing assumptions include test of normality, multicolinearity, and heteroscedasticity are used in this study. While the data analysis techniques used in this study is the analysis multiple linear regression with SPSS 16.0 program. Multiple linear regression model in the study this is:

$$
\begin{array}{ll}
P I=\alpha+ & \beta 1 R E L+\beta 2 H A+\beta 3 H C+\beta 4 F I+e \\
\alpha & =\text { Constanta } \\
\text { PI } & =\text { Purchase Intention } \\
\text { REL } \quad=\text { Religosity }
\end{array}
$$

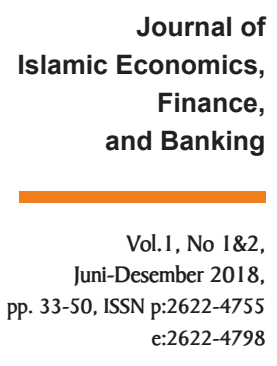

conomics,

Finance,

Desember 2018, e:2622-4798 


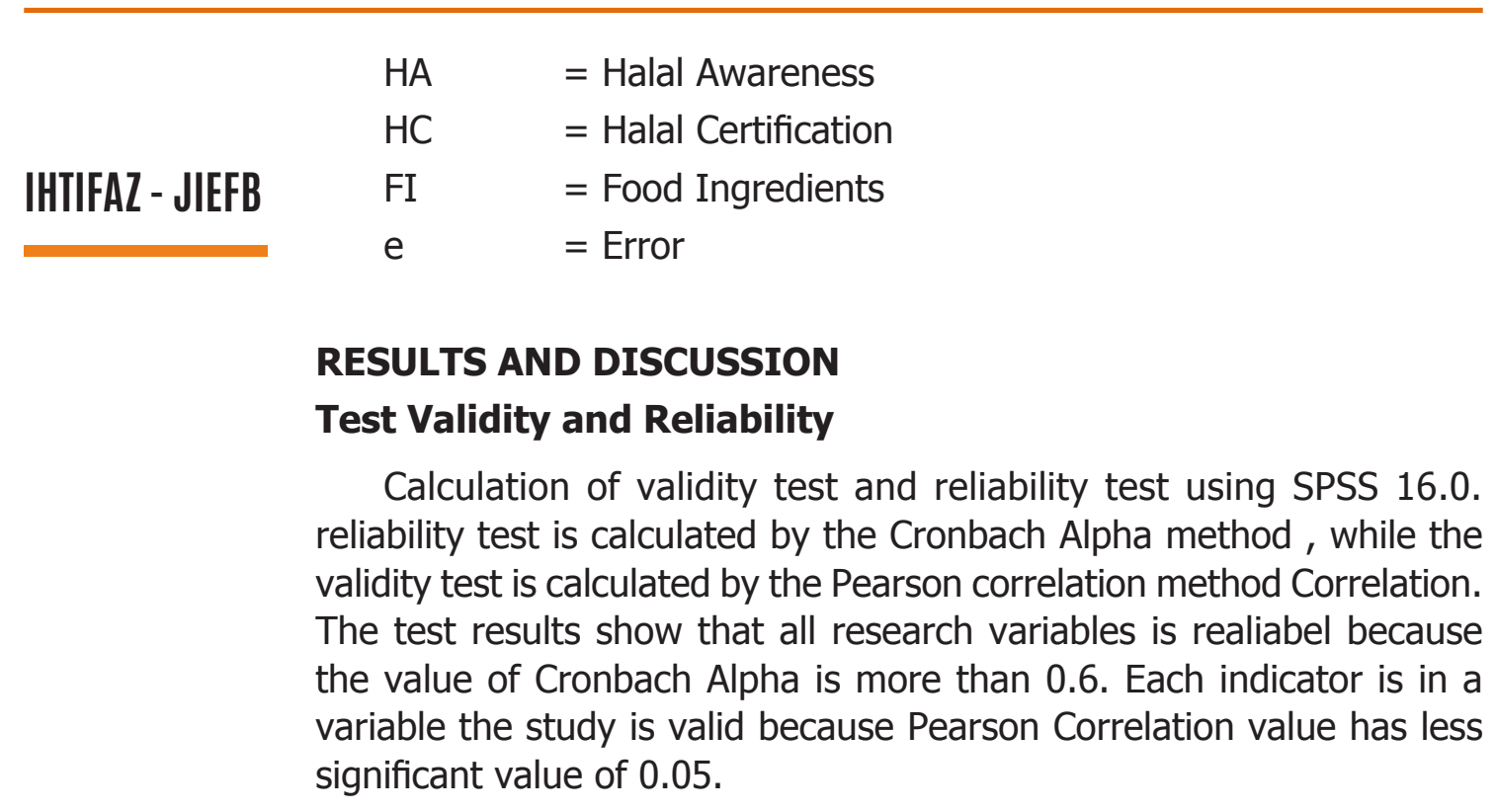

\section{Classic Assumption Test Results}

The results obtained from data analysis with SPSS 16.0 program. Testing assumptions include test normality, multicolinearity, and heteroscedasticity. Normality assumption test results can be concluded that this study pass the normality test because the points are spread and in the direction of the diagonal line. Besides using normal $p$ plot, this study also uses Kolmogorov Smirnov (KS) test. The value of significant is more than $0.05(0.428)$, then it can be said to pass the normality test.

The multicollinearity test is performed by looking at Tolerance and VIF values, if the Tolerance value is more than 0.10 and VIF less than 10, it is said to pass the multicolinearity test. So there is no independent variables are highly correlated in this study. Test results can be concluded that in this research there is no multicollinearity in all independent variables. This is because each variable has a tolerant value of more than 0.10 and VIF less than 10.

Heteroscedasticity test is done by glejser test method, that is by absolute the residual value then make the new variable as dependent variable in its regression. If a significant value of $t$ test is greater than 0.05 then there can be no heteroscedasticity in the study. Based on the results, it can be concluded that there are heteroscedasticity on two variables, namely halal certification and food composition. However, this heteroscedasticity does not result in significant changes to the results of the study so that research is still allowed to proceed.

\section{Descriptive Statistics}

Table 1 respondent demographic data shows the demographics of research respondents covering types sex, age, and occupation. 
Table 1. Respondent Demographic Data

\begin{tabular}{llll}
\hline Characteristics & Group & Total & Percentage \\
\hline Sex & Male & 66 & $32 \%$ \\
& Female & 139 & $68 \%$ \\
Old & Total & 205 & $100 \%$ \\
& $<16$ tahun & 0 & $0 \%$ \\
& $16-20$ tahun & 23 & $11 \%$ \\
& $21-25$ tahun & 115 & $56 \%$ \\
& $25-30$ tahun & 48 & $23 \%$ \\
& $>30$ tahun & 19 & $9 \%$ \\
Occupation & Total & 205 & $100 \%$ \\
& & & \\
& Student & 88 & $43 \%$ \\
& Civil Servant & 7 & $3 \%$ \\
& Private Worker & 50 & $24 \%$ \\
& Teacher/Lecturer & 19 & $9 \%$ \\
& Enterpreneur & 9 & $4 \%$ \\
& Others & 32 & $16 \%$ \\
& Total & 205 & $100 \%$ \\
\hline
\end{tabular}

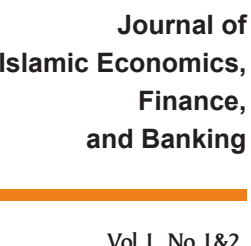

i-Desember 2018, pp. 33-50, ISSN p:2622-4755 e:2622-4798

Source: Data Result (2018)

Table 1 shows that female respondents were 139 people (68\%) and male as many as 66 people (32\%). Respondents had the most age range between 21 up to 25 years as many as 115 people (56\%) and the least is the age of more than 30 years as many as 19 people $(9 \%)$. The majority of respondents is students (42\%) and at least is Civil Servant (3\%).

This study also tries to look at consumer knowledge related to halal literacy in Indonesia through Table 2 below:

Table 2. Halal Knowledge Level of Respondents

\begin{tabular}{lcr}
\hline \multicolumn{1}{c}{ Halal Information } & Total & Percentage \\
\hline Kindergarten & 67 & $33 \%$ \\
Primary School & 101 & $49 \%$ \\
Junior High School & 20 & $10 \%$ \\
Senior High School & 12 & $6 \%$ \\
University & 5 & $2 \%$ \\
Source of Halal Information & & \\
Family & 169 & $82 \%$ \\
Friends & 3 & $1 \%$
\end{tabular}




\begin{tabular}{llcc}
\hline & & \\
& Book/Magazine/Newspaper & 9 & $4 \%$ \\
IHTIFAZ - JIEFB & Radio/TV & 11 & $5 \%$ \\
& Internet/Social Media & 7 & $3 \%$ \\
& Seminar & 3 & $1 \%$ \\
& Others & 3 & $1 \%$ \\
Halal MUI Application & & \\
Yes & 55 & $27 \%$ \\
No & 150 & $73 \%$ \\
Website: halalmui.org & & $28 \%$ \\
Yes, I have & 57 & $72 \%$ \\
\hline
\end{tabular}

Source: Data Result (2018)

These data indicates that the most important food-related information source is a family and started in the level of primary school education. While related to halal literacy from Majlis Ulama Indonesia (MUI), there are many people still do not take advantage of Halal MUI applications in mobile phones and have never been browse information from halalmui.org website.

\section{Hypothesis Test Results}

The results obtained from data analysis with SPSS 16.0 program using multiple linear regression analysis method. Hypothesis testing includes $t$ test, $F$ test, and coefficient determination $\left(R^{2}\right)$.

Table 3. Result of Multiple Linier Regression Analysis

\begin{tabular}{lrrr}
\hline \multicolumn{1}{c}{ Variables } & $\begin{array}{c}\text { Coefficients } \\
\text { of regression }\end{array}$ & t-statistics & Significant \\
\hline Religosity & 0.290 & 3.151 & 0.002 \\
Halal Awareness & 0.189 & 2.571 & 0.013 \\
Halal Certification & 0.076 & 2.537 & 0.012 \\
Food Ingredients & 0.157 & 3.099 & 0.002 \\
Constant & 6.436 & & \\
R $^{2}$ & 0.400 & & \\
Adjusted R & 0.388 & & \\
F-Statistics & 33.391 & & \\
Significant & 0.000 & & \\
\hline
\end{tabular}

Source: Data Result (2018)

Based on the results of Table 3 above, it can be said that the coefficient of determination by using Adjusted $R$ Square value is 0,388 . 
It means variables of religiosity, halal awareness, halal certification, and food ingredients can explain the variable of purchase intention of halal food by $38.8 \%$. While the remaining $61.2 \%$ is explained by other variables outside the study. The result of $F$ test above, the significant value of $F$ test is $0.000(<0,05)$. This means there are significant influences of religious variables, halal awareness, halal certification, and food ingredients to purchase intention variable in halal food simultaneously.

Based on the results of multiple linear analysis above, the equation model in this study are as follows:

$$
P I=6,436+0,290 R E L+0,189 H A+0,076 H C+0,157 F I
$$

\section{First Hypothesis}

Based on the results of hypothesis testing, the religiosity variable has a regression coefficient value 0.290 with a significant level 0.002 $(<0.05)$. This shows that the religiosity variable has positive and significant effect on purchase intention variable at a significant level of $5 \%$. So it can be concluded that the first hypothesis is accepted.

\section{Second Hypothesis}

Based on the results of hypothesis testing, halal awareness variable has a regression coefficient value 0.189 with a significant level 0.013 $(<0.05)$. This shows that halal awareness variable has positive and significant effect on purchase intention variable at a significant level of $5 \%$. So it can be concluded that the second hypothesis is accepted.

\section{Third Hypothesis}

Based on the result of hypothesis testing, halal certification variable has regression coefficient value 0,076 with significant level 0,012 $(<0,05)$. This shows that halal certification variable has positive and significant effect on purchase intention variable at a significant level of $5 \%$. So it can be concluded that the third hypothesis is accepted.

\section{Fourth Hypothesis}

Based on hypothesis test result, food composition variable has regression coefficient value 0.157 with significant level $0.002(<0.05)$. This shows that food composition variable has positive and significant effect on the variable of purchase intention at a significant level of $5 \%$. So it can be concluded that the fourth hypothesis is accepted. 


\section{DISCUSSION}

This study aims to see the halal awareness of Muslim consumers IHTIFAZ - JIEFB in Indonesia. This study also examines the effect and explain the role of religiosity, halal awareness, halal certification and food ingredients composition on purchase intention of halal food. The first hypothesis shows that there is positive and significant effect of the religiosity on purchase intention. The religious beliefs that follow will lead a person to obey his religious rules. The behavior of halal consumption is an implementation of the religious adherence of a Muslim. The impact of religiosity on purchase intention in halal food can be due to the life of a Muslim's religion has become a lifestyle so that all aspects of his life will be based on his religious beliefs. The results of this study support previous research by Machali et al. (2013) in Brunei Darussalam, Majid et al. (2015) in Pakistan, Ahmad et al. (2015) in Malaysia.

The second hypothesis shows positive and significant effect of halal awareness on purchase intention. This halal awareness is related to the level of knowledge Muslim consumers to understand which is appropriate with sharia and which are not. Halal awareness is likely to continue to increase in accordance with the development of media and technology, so that consumer purchase intention in halal products will also increase. Indonesia is trying to become a center for halal industry in the world. So as to trigger the halal certification of producers and also the government to provide quality halal products to meet the needs of Muslim. The results of this study support several previous studies conducted by Aziz and Vui (2013), Windikusuma (2015), Waskito (2015), and Bashir et al. (2018).

The third hypothesis shows a significant positive effect of halal certification on purchase intention. Halal certification is a guarantee that the goods consumed are completely halal according to Islam and guaranteed quality and safety. This halal certification has a validity period that must be extended to maintain a guaranteed halal quality. Halal label on the product is a sign of guarantee of halal certification from MUI. Consumers will pay attention to halal labels on packaging products or halal certificates in the restaurant before deciding to purchase. The results of this study support several previous studies conducted by Waskito (2015), Majid et al. (2015), Ghadikolaei (2016), Sumadi (2016), Kamilah and Wahyuati (2017). However, Listyoningrum and Albari (2012) research indicates that halal certification is not an issue for Muslim consumers for the products in their research. So without extending halal certification, consumers are not too concerned.

The fourth hypothesis shows a significant positive effect of food ingredients on purchase intention. In addition to halal labeling on the packaging, there is also a label of ingredients composition on the product. This is in accordance with the Law and other regulations related to products circulating in Indonesia. The composition of this 
food is very important to be considered by a consumer, especially for Muslims related to the content of the materials used whether halal or not. A conscientious consumer will check the ingredients in each pack or even ask the restaurant whether the food ingredients and tools used are completely free of unlawful elements. The results of this study support several previous studies conducted by Waskito (2015) and Hussain et al. (2016).

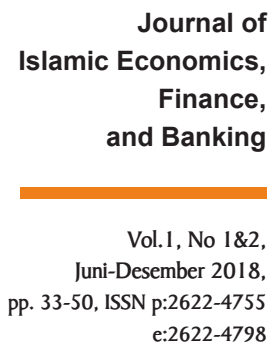

\section{CONCLUSIONS}

Based on the results of data analysis and discussion, it can be concluded that all the independent variables in the research are religiosity, halal awareness, halal certification, and food ingredient has positive and significatn effect on consumer purchase intention on halal food either simultaneously or partially. The role of religiosity is to control customer behavior on purchase intention of halal food. This indicates that the higher the level of obedience of a person in religion then the purchase intention halal food higher. The existence of halal awareness in a person will also affect the purchase intention. In addition, halal certification through halal labels and food ingredient on packaging also affects purchase intention of Muslim consumers in Indonesia against halal food products.

The existence of positive and significant influence of these four variables on consumer purchase intention can be a good idea for manufacture company and government to work together to improve halal certification standards. It aims to make halal food products that are the main needs of Muslims especially in Indonesia have security and health insurance for consumers. In addition, the need for halal food knowledge both in religious teachings and from community awareness itself needs to be improved through educational institutions and various media technology support that can be used today.

For entrepreneurs, this halal industry sector can be a company strategy to be able to adapt and provide appropriate needs of Muslim consumers. Actually the need for halal food is not only enjoyed by Muslims in Indonesia, but also Muslims in other countries, especially those who still have limitations in the provision of halal food, so that entrepreneurs can increase the export of halal food products from Indonesia.

For academics, this study is expected to increase the literature related to the study of halal food and can be developed for subsequent research. As for the community, this study is expected to increase insight and knowledge of awareness to consume halal food. This study has limitations because of the small number of samples when compared with a population of Muslims in Indonesia. This research can be developed with adding variables, samples, research sites in countries with limited of food halal, as well as using different analytical methods. 


\section{REFERENCES}

IHTIFAZ - JIEFB

Abdul Aziz, Y. \& Vui, C. N. (2013). The Role of Halal Awareness, Halal Certification and Marketing Components in Determining Halal Purchase Intention Among Non-Muslims in Malaysia: A Structural Equation Modelling Approach. Journal of International Food \& Agribusiness Marketing.

Ahmad, Ahlam N., Rahman, A., \& Rahman. S. (2015). Assesing Knowledge and Religiosity on Consumer Behavior towards Halal Food and Cosmetic Products. International Journal of Social Science and Humanity, 5 (1), 10-14.

Alfarisi, Muhammad Salman. (2017). Preferensi Masyarakat Terhadap Pembelian Produk Makanan Halal di Dusun Mlangi Yogyakarta. Thesis, Postgraduate Program, Indonesia Islamic University, Yogyakarta.

Allport, W.G and J. M. Ross. (1967). Personal Religious Orientation and Prejudice. Journal of Personality and Social Psychology. 5 (4), 432-443.

Ardyanti, Nor., Nashril, Tunku., \& Helmi, Mohd Helmi. (2013) "A Study on Halal Food Awareness Among Muslim Customers in Klang Valley". 4th International Conference on Business and Economic Research (4th ICBER) Proceeding, 1073-1087.

Bashir, Abdalla M., Bayat, A., Olutuase, S.O., \& Latiff, Z.A. (2018). Factors Affecting Consumers' Intention Towards Purchasing Halal Food in South Africa: A Structural Equation Modelling. Journal of Food Products Marketing.

Fatmawati, Indah \& Pramintasari, T.R. (2017). Pengaruh Keyakinan Religius, Peran Sertifikasi Halal, Paparan Informasi, dan Alasan Kesehatan Terhadap Kesadaran Masyarakat Pada Produk Makanan Halal. 734-765.

Ghadikolaei, Fatemeh Shabani. (2016). The Effect of Halal Signs and Symptoms on Consumers' Purchase Intention in Muslim and NonMuslim Countries- A Review. International Journal of Business and Management Invention, 5 (7), 44-49.

Ghozali, Imam. (2011). Aplikasi Analisis Multivariate dengan Program IBM SPSS 19. Semarang: Badan Penerbit Universitas Diponegoro.

Hussain, Iftikhar., Rahman Zaheer A., \& Saleem A. (2016). Integrating Factors Influencing Consumers' Halal Products Purchase: Application of Theory of Reasoned Action. Journal of International Food \& Agribusiness Marketing, 28 (1), 35-58. 
Kamilah, Ghina dan Aniek Wahyuati. (2017). Pengaruh Labelisasi Halal dan Brand Image Terhadap Keputusan Pembelian Melalui Minat Beli. Jurnal Ilmu dan Riset Manajemen, 6 (2).

Lada, S., Tanakinjal, H.G., \& Amin, H. (2009). Predicting Intention to Choose Halal Products using Theory of Reasoned Action. International Journal Islamic and Middle Eastern Finance and Management, 2 (1), 66-76.

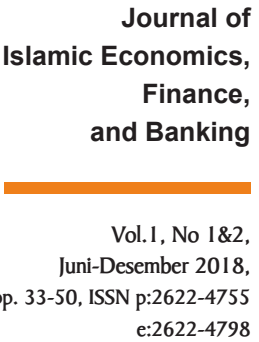

Listyoningrum, Anggit \& Albari. (2012). Analisis Minat Beli Konsumen Muslim Terhadap Produk yang Tidak Diperpanjang Sertifikat Halalnya. Jurnal Ekonomi dan Keuangan Islam. 2 (1), 40-51.

Machali, M., Rose A., \& Razak, L.A. (2013). The Effect of Halal Awareness on Purchase Decision with Religiosity as A Moderating Variable: A Study at Higher Education Institutions in Brunei Darussalam. Available from https://www.researchgate.net/publication/288713193.

Majid, M.B., Sabir I., \& Ashraf T. (2015). Consumer Purchase Intention towards Halal Cosmetics \& Personal Care Products in Pakistan. Global Journal of Research in Business \& Management, 1 (1), 45-53.

Pew Research Center. (2017). The Changing Global Religious Landscape. Available from www.pewresearch.org.

Shaari, Jamal A.N. \& Arifin, N.S. (2010). Dimension of Halal Purchase Intention: A Preliminary Study.

Sumadi. (2016). Peranan Kepercayaan Kepada Penjual dan Label Halal Terhadap Minat Beli Daging Halal. BENEFIT Jurnal Manajemen dan Bisnis, 1 (2), 120-130.

Waskito, Danang. (2015). Pengaruh Sertifikasi Halal, Kesadaran Halal, dan Bahan Makanan Terhadap Minat Beli Produk Makanan Halal (Studi Pada Mahasiswa Muslim di Yogyakarta). Thesis, Faculty of Economics, Yogyakarta State University, Yogyakarta.

Windikusuma, Dewi Kirana.(2015). Pengaruh Kesadaran Halal Terhadap Sikap dan Implikasinya Terhadap Minat Beli Ulang. Thesis, Faculty of Economics and Business, Diponegoro University, Semarang.

Yasid. Farhan, Fikri \& Andriansyah, Yuli. (2016). Factors Affecting Muslim Students Awareness of Halal Products in Yogyakarta, Indonesia. International Review of Management and Marketing, Asia International Conference (AIC 2015), 27-31.

Keputusan Menteri Agama Republik Indonesia Nomor 519 Tahun 2001 tentang Lembaga Pelaksanna Pemeriksaan Pangan Halal.

Undang-Undang Republik Indonesia Nomor 33 Tahun 2014 tentang Jaminan Produk Halal 
. 2017. Islam akan Menjadi "Agama Terbesar" pada 2075. www. bbc.com/indonesia/amp/majalah-39510081

IHTIFAZ - JIEFB

.TT. Survei: Populasi Muslim di Eropa Akan Meningkat. www.amp.dw.com/id/survei-populasi-muslim-di-eropa-akanmeningkat/a-41598756

www.e-Ippommui.org

www.halalmui.org

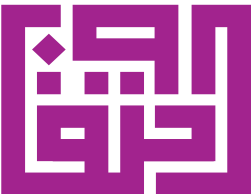

\section{IHTIFAZ}

UNIVERSITAS AHMAD DAHLAN 